\title{
ДИЗАЙН АНТИБАКТЕРИАЛЬНЫХ \\ И БАКТЕРИЦИДНЫХ СРЕДСТВ НА ОСНОВЕ МАКРОЦИКЛИЧЕСКИХ СОЕДИНЕНИЙ
}

\author{
О.С. Терентьева, П.Л. Падня, Ю.Г. Штырлин, И.И. Стойков \\ Казанский (Приволжский) Федеральный Университет, Казань, Россия \\ 420008, Россия, г. Казань, ул. Кремлёвская, 18.
}

DOI: 10.19163/MedChemRussia2021-2021-340

E-mail: olga-potrekeeva@mail.ru

Поиск новых антибактериальных и антисептических препаратов является актуальной задачей в связи с устойчивостью микроорганизмов к существующим лекарствам. Медицинская химия макроциклических соединений в последние годы активно развивается. Уникальные свойства тиакаликсарена (конформационная подвижность и дополнительные координационные центры) позволяют легко получать стереоизомеры с различным расположением функциональных групп в пространстве, что перспективно для создания новых биологически активных соединений.
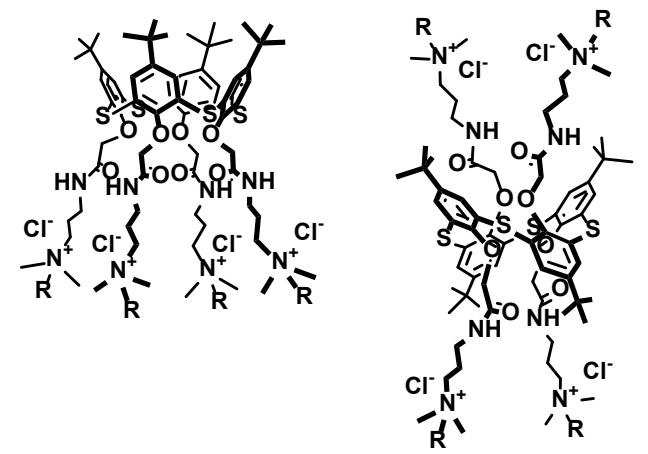

$$
\begin{aligned}
& \mathrm{R}= \\
& \mathrm{CH}_{3} \\
& \mathrm{C}_{4} \mathrm{H}_{9} \\
& \mathrm{C}_{8} \mathrm{H}_{17} \\
& \mathrm{C}_{10} \mathrm{H}_{21} \\
& \mathrm{CH}_{2} \mathrm{C}_{6} \mathrm{H}_{5}
\end{aligned}
$$

В рамках этой работы с высокими выходами были синтезированы тетразамещенные четвертичные аммониевые соли на основе п-трет-бутилтиакаликс[4]арена. Полученные соединения обладают высоким антибактериальным действием в отношении грамположительных (S. aureus, S. epidermidis, B. subtilis) бактерий, сравнимым с известными антисептиками хлоргексидином, мирамистином и бензалкония хлоридом. Установлено, что четвертичные аммониевые производные тиакаликс[4] арена в конформации 1,3-альтернат эффективнее подавляют рост исследуемых бактериальных штаммов, чем соединения в конформации конус. Исследования цитотоксичности на клетках фибробластов кожи человека (HSF) выявили, что все соединения менее токсичны по сравнению с контрольными препаратами. Полученные результаты открывают возможность создания новых эффективных антибактериальных и антисептических препаратов на основе макроциклических соединений.

Работа выполнена при финансовой поддержке Российского научного фонда (No. 19-73-10134). 